\title{
PELATIHAN PENGELOLAAN TAMAN BACAAN MASYARAKAT BENING SAGULING FOUNDATION
}

\author{
${ }^{1}$ Abdul Wahab, ${ }^{2}$ Fajar Abdilah \\ IKIP Siliwangi \\ 19abdulancam@gmail.com, 2fajarabdlh28@gmail.com
}

\begin{abstract}
ABSTRAK
Penelitian ini dilatarbelakangi oleh permasalahn yang ditemukan TBM Bening Saguling yaitu pelayanan di taman baca yang kurang optimal, dikarenakan kurangnya professional pengelolaan dalam mengurus TBM. Tujuan penelitian ini adalah untuk mengetahui bagaimana pelatihan pengelolaan TBM. Teori yang digunakan diantaranya, konsep TBM, konsep pelatihan dan konsep pengelolaan.Penelitian merupakan penelitian kualitatif dengan menggunakan pendekatan deskriptif. Penelitian ini penulis menggunakan teknik wawancara, dokumentasi. Yang menjadi responden dalam penelitian ini berjumlah 12 orang, yang terdiri dari satu orang ketua pengelola, satu orang pengurus dan sepuluh anggota komunitas citarum kids. Kegiatan pelatihan pengelolaan TBM yaitu dalam bentuk melatih peserta membuat kartu katalog, pembuatan buku induk dan peminjaman, pembuatan rak buku dan melatih membuat proposal untuk menambah pengadaan bahan IPTEK untuk disimpan di TBM.
\end{abstract}

Kata kunci : Pelatihan, Pengelolaan, TBM.

\section{PENDAHULUAN}

Meningkatkan kualitas masyarakat baik dari segi ekonomi, pendidikan dan kesehatan merupakan garapan jurusan Pendidikan Masyarakat secara konseptor maupun praktik langsung. Dalam hal ini perlu adanya pengidentifikasian secara dini demi menemukan potensi yang dapat diangkat untuk meningkatkan kualitas masyarakat tersebut dan sudah barang tentu diperlukan tempat pengidentifikasian. Tempat kali ini yang menjadi garapan adalah Taman Bacaan Masyarakat (TBM) Bening Saguling Foundation.

Tercatat sekitar 5.000 taman bacaan di Indonesia berpotensi mengembangkan program literasi lokal dari komunitas lokal. Selama ini, sejumlah fasilitas membaca, seperti perpustakaan, terasa menakutkan karena terkesan hanya orang sekolahan yang boleh masuk ke dalam. Taman baca bisa berada di lingkungan masyarakat dengan maksud menumbuhkan minat baca, karena mudah diakses masyarakat, tidak eksklusif, dan membumi. Di TBM, masyarakat setempat dapat memperoleh berbagai referensi, sekaligus menjadi wadah bagi komunitas untuk beraktivitas sesuai karakter dan potensi daerah tersebut. 
Melihat kenyataan yang ada akan pentingnya TBM demi meningkatkan kualitas masyarakat dalam segi pendidikan maka perlu diadakan suatu kegiatan yang memberikan informasi secara utuh mengenai bagaimana mengelola taman bacaan masyarakat (TBM) yang baik demi terwujudnya taman baca yang sesuai dengan kebutuhan masyarakat. Oleh karena itu, peneliti mempunyai sebuah gagasan untuk melakukan sebuah penelitian tentang pelatihan pengelolaan taman baca masyarakat (TBM) kepada pengelola, khususnya kaum muda mengenai bagaimana mengelola taman bacaan masyarakat yang baik dimasa mendatang.

\section{KAJIAN TEORI}

\section{Taman Baca Masyarakat}

Apabila negara Indonesia ingin menjadi negara yang maju dan dapat bersaing dengan negara-negara yang sudah maju seperti singapura, jepang, inggris, dll. maka negara ini harus mempunyai masyarakat yang memiliki pengetahuan dan keterampilan yang sangat bagus dan berkualitas. Supaya memiliki pengetahuan dan keterampilan yang bagus dan kualitas, maka setiap warga negara harus mendapatkan pendidikan yang layak. Dalam pembukaan Undang-undang Dasar 1945 pasal 31 ayat 1 dinyatakan "bahwa setiap warga negara berhak mendapatkan pendidikan". Bunyi undang-undang tersebut telah mengisyaratkan bahwa negara sangat mendukung masyarakatnya dalam hal pendidikan, tinggal bagaimana pemimpin negara ini mendukung gerakan pendidikan yang ada.

Berdasarkan Undang-undang No. 2 tahun 1989 pasal 4 tentang Sistem Pendidikan Nasional menyatakan bahwa pengetahuan dapat dimiliki dengan cara membaca. Melalui kegiatan membaca maka masyarakat dapat belajar dan memperluas wawasan, memperoleh berbagai informasi yang bermanfaat dan dapat menghibur diri. Salah satu cara untuk mencerdaskan kehidupan bangsa adalah dengan menggalakkan budaya membaca. Tujuan dari kegiatan ini adalah mewujudkan masyarakat gemar belajar (learning society), salah satu indikatornya adalah masyarakat yang gemar membaca (Reading Society).

Salah satu cara untuk membangkitkan budaya gemar membaca adalah dengan tersedianya TBM. Taman Bacaan Masyarakat adalah sebuah lembaga yang menyediakan bahan bacaan yang dibutuhkan oleh masyarakat. Sedangkan bahan pustaka yang berada di TBM adalah semua jenis bacaan dalam berbagai bentuk media.

Beberapa tahun lalu Depdiknas mendorong tumbuhnya TBM. Hal ini merupakan salah satu kegiatan dari program peningkatan budaya baca dan pembinaan dan pembinaan perpustakaan yang digalakkan oleh Direktorat Diknas, Ditjen Pendidikan Nonformal dan informal. Untuk mencapai keinginan tersebut, diperlukan adanya kesediaan masyarakat untuk membentuk sebuah TBM. Dari sini pada akhirnya berkembang menjadi perpustakaan. Selanjutnya Depdiknas berupaya menyediakan bahan bacaan yang bisa diakses oleh masyarakat sesuai kebutuhan di daerah masing-masing. 


\section{Pelatihan}

Istilah pelatihan sering merujuk kepada cara untuk memperoleh pengetahuan dan keahlian-keahlian sebagai sebuah hasil dari pembelajaran mengenai kejuruan atau keahlian praktis dan pengetahuan yang berhubunga dengan kompetensi - kompetensi spesifik yang berguna.

Edwin B. Flippo (Kamil, 2012, hal. 3)mengemukakan bahwa : "Training is the act of increasing the knowledge and skill of an employee for doing a particular job" (pelatihan adalah tindakan meningkatkan pengetahuan dan keterampilan seorang pegawai untuk melaksanakan pekerjaan tertentu.). Sedangkan menurut Simamora (Kamil, 2012, hal. 4), mengartikan pelatihan sebagai serangkaian aktivitas yang dirancang untuk meningkatkan keahlian-keahlian, pengetahuan, pengalaman ataupun perubahan sikap seorang individu.

Dengan demikian dapat disimpulkan pelatihan adalah serangkaian kegiatan seorang pegawai dalam meningkatkan keahlian, pengetahuan, keterampilan, pengalaman, naupun perubahan sikap dalam suatu pekerjaan tertentu.

\section{Pengelolaan}

Menurut Sudjana (2010, hal. 17) manajemen atau pengelolaan mengandung pengertian "kemampuan dan keterampilan khusus untuk melakukan suatu kegiatan, baik bersama orang lain atau melalui orang laindalam mencapai tujuan organisasi". Sedangkan menurut Hersey dan Blanchd (Sudjana, 2010, hal. 17) 'Management as working with and through individuals and group to accomplish organizational goalds'. Pengelolaan disini berarti suatu kegiatan yang dilakukan bersama bisa melalui individu atau kelompok untuk mencapai tujuan-tujuan organisasi.

Dari pengertian diatas, dapat disimpulkan bahwa managemen atau pengelolaan adalah suatu kegiatan yang dilakukan secara bersama-sama atau berkelompok untuk mencapai tujuan yangditetapkan dalam sebuah organisasi.

\section{METODE PENELITIAN}

Metode penelitian yang digunakan penulis dalam penelitian ini adalah metode penelitian analisis deskriptif dengan pendekatan kualitatif. Metode kualitatif adalah metode penelitian yang berlandaskan pada filsafat post positivisme, digunakan untuk meneliti pada kondisi objek yang alamiyah. Dimana peneliti adalah sebagai instrumen kunci, teknik pengumpulan data dilakukan secara triangulasi (gabungan), analisis data bersifat induktif/ kualitatif, dan hassil penelitian kualitatif lebih menekankan makna daripada generalisasi (Sugiyono, 2015).

Penelitian ini dilakukan di Taman Bacaan Masyarakat Bening Saguling kp. Babakan cianjur, Cihampelas, Bandung Barat. Yang menjadi informan dalam penelitian ini berjumlah 12 orang, yang terdiri dari satu orang Ketua pengelola TBM, satu orang Pengurus dan sepuluh anggota komunitas Citarum kids. Guna memperoleh data yang diperlukan dalam penelitian ini penulis menggunakan teknik wawancara, dokumentasi. 
Selanjutnya, setelah data terkumpul penulis melakukan tahapan reduksi data, penyajian data, dan penarikan kesimpulan.

\section{HASIL DAN PEMBAHASAN}

\section{Hasil}

Taman Bacaan Masyarakat di Yayasan Bening Saguling kampung babakan cianjur, Desa Cihampelas, kec. Cihampelas, kab. Bandung barat. Taman baca masyarakat ini ada sudah cukup lama ada namun pelayanan di taman baca kurang optimal, dikarenakan kurangnya professional pengelolaan dalam mengurus taman bacaan tersebut. Taman bacaan masyarakat bening saguling ini berisi berbagai macam buku bacaan. Seperti komik, buku lingkungan, buku cerita, buku pelajaran, dll. Banyaknya jenis buku yang disimpan di TBM ini diharapkan dapat menarik minat dari para warga sekitar TBM untuk mau membaca. Apabila sudah banyak warga masyarakat yang mau membaca di TBM ini, maka akan tercipta suatu masyarakat yang gemar/ hobi membaca.

Kegiatan pelatihan pengelolaan Taman Bacaan Masyarakat yaitu dalam bentuk melatih peserta membuat kartu katalog, pembuatan buku induk dan peminjaman, pembuatan rak buku dan melatih membuat proposal untuk menambah pengadaan bahan IPTEK untuk disimpan di TBM.

Dalam kegiatan pelatihan ini peserta berjumlah 12 orang, yang terdiri dari satu orang Ketua pengelola TBM, satu orang Pengurus dan sepuluh anggota komunitas Citarum kids. Banyaknya peserta pelatihan yang masih muda, diharapkan mereka nantinya dapat mengelola TBM dengan baik, dikarenakan mereka masih mempunyai semangat untuk belajar yang sangat tinggi.

Hasil dari kegiatan ini berupa memberikan pelatihan bagaimana mengelola TBM serta dibuatkan sebuah tempat taman bacaan masyarakat yang baru.

\section{Pembahasan}

TBM Bening Saguling merupakan TBM yang berdiri dan berkembang untuk mengembangkan minat baca dalam lingkungan masyarakat setempat maupun kepedulian untuk memberdayakan masyarakat melalui bahan-bahan. Berdasarkan kepedulian akan pentingnya membaca dan tidak jarang muncul dari pribadi - pribadi yang sudah menjadikan buku sebagai bagian dari hidup mereka dan muncul keinginan berbagi dengan masyarakat. Terlepas dari penggagas, berkembang nya TBM pada dasarnya mempunyai tujuan yang sama yaitu memupuk kegemaran membaca.

Sutarno (2006, hal. 75-77) menjelaskan bahwa status atau kedudukan dan organisasi perpustakaan merupakan suatu hal yang penting. Status perpustakaan berkaitan erat dengan struktur organisasi nya. Artinya tinggi atau rendahnya status perpustakaan tergantung pada luas atau sempitnya ruang lingkup dan jenjang organisasi. Perpustakaan yang memiliki organisasi yang lebih besar semestinya menduduki status yang tinggi, perpustakaan yang kecil organisasi nya juga statusnya relatif rendah. 
Pengelola adalah orang atau lembaga yang menaruh minat dan melaksanakan rangkaian kegiatan mulai dari perencanaan, pengorganisasian, pelaksanaan, sampai dengan pemantauan dan penilaian suatu program atau kegiatan. Sedangkan program TBM belum dapat dikatakan berhasil apabila kemampuan, keterampilan, dan kinerja pengelola belum memadai untuk mengelola TBM, sehingga bagi para pengelola TBM agar dapat mengikuti pelatihan yang berhubungan dengan penyelenggaraan TBM sebelum melaksanakan tugasnya.

Menurut Naskah Akademik Pengelolaan Taman Bacaan Masyarakat (Depdiknas, 2008; 24) tugas - tugas pengelola Taman Bacaan Masyarakat adalah :

a. Melakukan sosialisasi promosi mengenai bahan bacaan yang ada di taman bacaan masyarakat bagi masyarakat sekitar

b. Melakukan kajian sederhana untuk mendapatkan data profil masyarakat yang akan di layani sehingga jenis bacaan yang di sediakan sesuai dengan kebutuhan masyarakat.

c. Melakukan layanan membaca, meminjam, melakukan berbagai aktivitas untuk meningkatkan kemampuan membaca, minat belajar dan lain - lain.

d. Menata bahan bacaan di ruang display bahan bacaan.

Dari uraian di atas dapat disimpulkan bahwa tugas pengelola Taman bacaan masyarakat adalah mempromosikan bahan bacaan yang ada di TBM bagi masyarakat sekitar dan keberadaan taman bacaan masyarakat itu sendiri.

\section{KESIMPULAN}

Taman Bacaan Masyarakat adalah sebuah lembaga yang menyediakan bahan bacaan yang dibutuhkan oleh masyarakat. Disisi lain TBM dijadikan sebagai tempat membaca dan belajar, sekaligus sebagai tempat untuk mendapatkan informasi bagi masyarakat. Untuk memelihara keberadaan taman bacaan masyarakat (TBM) diperlukan berbagai alternatif dalam pengelolaannya, sehingga warga belajar dapat memanfaatkan taman bacaan secara maksimal.

Pelatihan yang dilakukan yaitu dalam bentuk melatih peserta membuat kartu katalog, pembuatan buku induk dan peminjaman, pembuatan rak buku dan melatih membuat proposal untuk menambah pengadaan bahan IPTEK untuk disimpan di TBM.

\section{DAFTAR PUSTAKA}

Depdiknas. (2008). Naskah Akademik Pengelolaan Taman Bacaan Masyarakat. Jakarta: Direktorat Jendral Peningkatan Mutu.

Ansori, A \& Samsudin, A. (2013). TRANSFORMASI PEMBELAJARAN DI PENDIDKAN NON FORMAL (Upaya mempersiapkan pendidik dan peserta didik dalam menghadapi tantangan global untuk menjadi manusia pembelajar). Empowerment, 2(1), 1-15

Kamil, M. (2012). Model Pendidikan dan Pelatihan (Konsep dan Aplikasi). Bandung: Alfabeta. 
Nirmalasari, T. \& Widiastuti, N. (2018). PERAN TOKOH PEMUDA DALAM MENINGKATKAN PARTISIPASI KARANG TARUNA DI DESA NANJUNG MARGAASIH. Comm-Edu (Community Education Journal), 1(2), 94-104

Saepudin, A. \& Mulyono, D. (2019). COMMUNITY EDUCATION IN COMMUNITY DEVELOPMENT. Empowerment, 8(1), 65-73

Sudjana, D. (2010). Manajemen Program Pendidikan. Bandung: Falah Production. Sugiyono. (2015). Metode Penelitian Kuantitatif, Kualitatif, dan R\&D. Bandung: Alfabeta. Sutarno. (2006). Perpustakaan dan Masyarakat. Jakarta: Sagungseto. 